\title{
An Assessment of Coliform Bacteria in Water Sources Near Appalachian Trail Shelters Within the Great Smoky Mountains National Park
}

\author{
Brian C. Reed, MD; Mark S. Rasnake, MD \\ From the Department of Medicine, University of Tennessee Graduate School of Medicine, Knoxville, TN.
}

\begin{abstract}
Objective.-Hikers and campers are exposed to risks while in the wilderness. One of these risks is the possibility of contracting an illness, including infectious diarrhea. This project tested for coliform bacteria in water samples taken near popular Appalachian Trail shelters.

Methods.-Water was collected from access points within the Great Smoky Mountains National Park. Samples were collected in sterile bottles and inoculated on a commercially available coliform detection kit for quantitative determination of total coliform and Escherichia coli counts.

Results.-Water samples were taken during summer and fall seasons. During summer, 7 of 10 samples were positive for coliform bacteria and 6 of those 7 for $E$ coli. The most probable number (MPN) of colony-forming units (CFU) for coliform bacteria ranged from 0 to $489 \mathrm{CFU} / 100 \mathrm{~mL}$, with the MPN for $E$ coli varying from 0 to $123 \mathrm{CFU} / 100 \mathrm{~mL}$. These data differed from the fall collection, revealing 3 of 7 samples positive for coliform bacteria and 1 of those 3 for $E$ coli. The MPN of CFU for coliform bacteria in fall samples varied from 0 to $119 \mathrm{CFU} / 100 \mathrm{~mL}$ and 0 to 5 to $\mathrm{CFU} / 100 \mathrm{~mL}$ for E coli.

Conclusions.-Environmental Protection Agency drinking water standards set the standard of 0 CFU/100 mL to be considered safe. This analysis of water samples along the Appalachian Trail emphasizes that the majority of water access points require treatment during the summer season. Coliform burden was not as high through the fall months. These data suggest one infectious disease risk for wilderness travelers.
\end{abstract}

Key words: water, hiking, coliform, bacteria, E coli

\section{Introduction}

Many Americans enjoy spending time outdoors. The National Survey on Recreation and the Environment estimated that during the 12 months before the survey, 24.5 million people age 16 or older backpacked once or more. ${ }^{1}$ The number of those enjoying hiking within the United States is increasing. ${ }^{2}$ One of the most popular hiking trails in the nation is the Appalachian Trail, especially the segment within Great Smoky Mountains National Park (GSMNP). In 2011, the US Department of Agriculture deemed the use of the entire Appalachian Trail in 2007 was $1,948,701$ visitors. $^{3}$

Presented in part at the American College of Physicians Annual Meeting, 2013, San Francisco, CA, and the Tennessee American College of Physicians Meeting, 2012, Chattanooga, TN.

Corresponding author: Brian C. Reed, MD, Methodist Medical Center of Oak Ridge, 990 Oak Ridge Turnpike, Oak Ridge, TN 37831-2529 (e-mail: brian_reed@teamhealth.com).
Hikers generally understand the risks of venturing into the wilderness, including potential musculoskeletal, skin, and gastrointestinal problems. Few studies regarding health risks and the overall healthcare of hikers have been conducted. ${ }^{2}$ With the growing public health implication, investigating the water quality of Appalachian Trail shelters is of interest.

\section{Methods}

To determine the current infectious risk of water along the Appalachian Trail in the GSMNP, a total of 10 evenly distributed shelters were selected. Appalachian Trail shelters may provide a piped water source from a creek or spring similar to the one at Davenport Gap in the Figure. During May and June (summer) and again in October and November (fall) of 2012, samples were collected directly into $500-\mathrm{mL}$ sterile bottles without disturbing the surroundings (National Park Service 


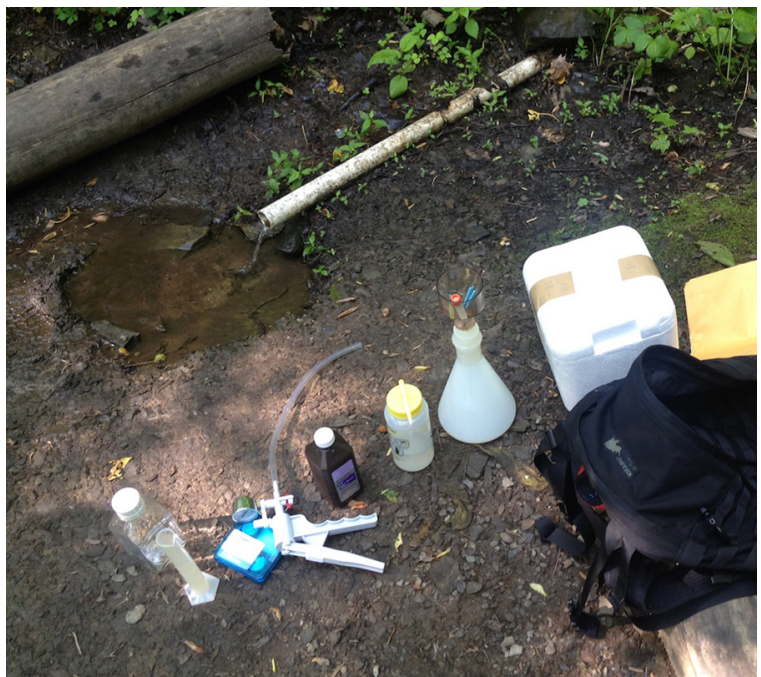

Figure. Water source at Davenport Gap.

Approval GRSM-2012-SCI-1112). The water was allowed to pour directly into the bottle without touching the pipe, and the bottle was not dunked within the collection of water under the source. All of the bottles were labeled and then transported at ambient temperature to the microbiology laboratory at the University of Tennessee Medical Center in less than 4 hours.

On arrival at the laboratory, the water was poured directly onto commercially available culture plates that specifically select for coliform bacteria (Coliplate, Bluewater Biosciences, Inc, Mississauga, Ontario, Canada). Enough sample water was poured over the culture plate to fill every well, with some unmeasured water remaining. These plates were incubated for 24 hours at $37^{\circ} \mathrm{C}$. After incubation, the number of wells seen under visible and ultraviolet (UV) light was counted. These media allowed detection of coliform bacteria based on a green to blue coloration within the wells under visible light. The addition of a UV light source provided identification of Escherichia coli among the wells that fluoresce.

\section{Results}

Seven of 10 samples were positive for coliform bacteria, and 6 of those 7 were also positive for $E$ coli during summer months. The results for fall months were 3 of 7 samples positive for coliform bacteria and 1 of those 3 for $E$ coli. Once the number of wells seen under visible and UV light was observed, correlation with a table provided by Bluewater Biosciences allowed estimation of the most probable number (MPN) of colony-forming units (CFU) per $100 \mathrm{~mL}$ of water. There was a wide variation between samples during the summer months, with MPN ranging from 0 to $489 \mathrm{CFU} / 100 \mathrm{~mL}$, and varying from 0 to $123 \mathrm{CFU} / 100 \mathrm{~mL}$ for $E$ coli. The MPN in fall months varied from 0 to $119 \mathrm{CFU} / 100 \mathrm{~mL}$ and 0 to 5 to $\mathrm{CFU} / 100 \mathrm{~mL}$ for $E$ coli. The Table provides the results for each shelter tested.

\section{Discussion}

A large and increasing number of Americans enjoy spending time in the outdoors. ${ }^{2}$ Hikers are exposed to health dangers while in the wilderness. Greater exposure to untreated, contaminated water increases a hiker's risk of acquiring a diarrheal illness. The prevalence of undifferentiated gastrointestinal illness among hikers of the Long Trail in Vermont from 1986 through 1998 was 7\% (11 of 155 persons). ${ }^{4}$ A study on medical problems during expedition activities at various National Outdoor

Table. Results from summer (May/June) and fall (Oct/Nov) collection

\begin{tabular}{|c|c|c|c|c|c|}
\hline Shelter name & Mileage $^{a}$ & $\begin{array}{c}\text { MPN of coliform } \\
\text { in summer }(C F U / \\
100 \mathrm{~mL})\end{array}$ & $\begin{array}{c}\text { MPN of E. coli in } \\
\text { summer }(C F U / \\
100 \mathrm{~mL})\end{array}$ & $\begin{array}{c}\text { MPN of coliform } \\
\text { in fall }(C F U / 100 \\
m L)\end{array}$ & $\begin{array}{c}\text { MPN of E. coli in } \\
\text { fall }(C F U / 100 \\
m L)\end{array}$ \\
\hline Mt Collins & 200.2 & 0 & 0 & 0 & 0 \\
\hline Derrick Knob & 186.7 & 0 & 0 & - & - \\
\hline Silers Bald & 192.2 & 339 & 123 & - & - \\
\hline Double Springs & 193.9 & 19 & 0 & 0 & 0 \\
\hline Tricorner & 220.3 & 182 & 19 & - & - \\
\hline Cosby Knob & 228 & 0 & 0 & 0 & 0 \\
\hline Davenport & 235.1 & 271 & 33 & 119 & 0 \\
\hline Russell Field & 177.5 & 317 & 3 & 83 & 0 \\
\hline Spence Field & 180.4 & 489 & 5 & 69 & 5 \\
\hline Icewater Spring & 207.7 & 59 & 13 & 0 & 0 \\
\hline
\end{tabular}

CFU, colony-forming units; MPN, most probable number.

${ }^{a}$ Mileage from Springer, GA. 
Leadership School courses determined the risk of gastrointestinal illness as 113 of 478 (23.6\%) cases of illness. ${ }^{5}$ A study in the late 1980 s by Crouse and Josephs ${ }^{6}$ queried 224 hikers who completed the entire 2100-mile Appalachian Trail regarding any health consequences. Of the $82 \%$ of hikers who responded to the query, $63 \%$ reported diarrhea. A prospective study with 280 of 334 interviewed revealed diarrhea had the highest incidence of reported illness at $56 \%$. $^{2}$

Previous evidence has shown that the majority of those who contract a gastrointestinal illness do not practice proper hygiene or do not treat their water adequately. ${ }^{7}$ Drinking untreated water significantly increased the risk of diarrhea (odds ratio [OR], 7.7; 95\% CI, 2.7-23; $P<.0001$ ), and that washing hands and cooking instruments decreased this risk ( $E$ coli, 0.46 ; 95\% CI, 0.22-0.97; $P=.04) .^{2}$ These findings were reinforced in a later study by Boulware ${ }^{8}$ that revealed a significant decrease in rates of diarrhea for those who consistently treated water $(45 \%)$ compared with those who were inconsistent (69\%; relative risk, 0.65 ; $95 \% \mathrm{CI}$, $0.53-0.81 ; P=.001)$. In the same study, those who practiced good hygiene, which was defined as cleaning cooking utensils and washing hands after defecation routinely, had decreased episodes of diarrhea (relative risk, 0.47; 95\% CI, 0.22-0.99; $P=.04){ }^{8}$

Previous studies have also demonstrated water contamination in the GSMNP, but most recently in $1982 .{ }^{9}$ Contamination of water with coliform bacteria can be from numerous sources, such as fecal contamination from humans or other animals adjacent to the water, or runoff from agriculture, storms, or sewage upstream. Given the open water source at shelters, it is possible contamination can occur from hikers with contaminated hands themselves grasping the pipe. , $^{2,9}$

There are efforts to inform the public of the need to treat water before consumption, such as signage at most Appalachian Trail shelters within the GSMNP and a Centers for Disease Control and Prevention publication. ${ }^{10}$ Treating contaminated water before imbibing may prevent illness. ${ }^{7}$ There are numerous methods of treating contaminated water, including iodine tablets, boiling water, filters, and UV light. This study again demonstrates the importance of water treatment for those who adventure outdoors.

\section{Limitations}

There were limitations to this study, which include a single sample per shelter and the inability to sample water at 3 sites during the fall months. This was because 1 site was without water from the source, and 2 were unreachable owing to an early season snowstorm.
Additionally, we were unable to specify pathogenic strains, only the total $E$ coli and coliforms burdens, so we cannot estimate how high the risk of illness is from the data. As all of the shelters were within the GSMNP, the results cannot be generalized for the entire Appalachian Trail.

\section{Conclusions}

Estimating water contamination by testing for an indicator organism such as coliform bacteria can be beneficial and is a standard means to estimate water pollution. ${ }^{11}$ Environmental Protection Agency drinking water standards require 0 coliform $\mathrm{CFU} / 100 \mathrm{~mL}$ as the maximum contaminant level goal. ${ }^{11,12}$ It was established that multiple water sources along the Appalachian Trail in the GSMNP exceeded this level during both rounds of sample collection. In addition, 1 shelter exceeded recreational water safety standards $(>100$ CFU/100 mL) during the summer sample (Silers Bald).

The reason for the coliform activity within the watershed is unclear. Regardless, this investigation confirms the need for water treatment practices in the wilderness and suggests waterborne infection risk for wilderness travelers. Diarrhea and gastrointestinal upset is a major inconvenience to hikers and more likely to spread, given the risk of contamination to water, existing water supplies, and person-to-person spread from food preparation without adequate sanitation. For this reason, it is important to educate outdoor enthusiasts on water purification as well as hygiene.

\section{Acknowledgments}

We would like to acknowledge the Physician's Medical Education and Research Foundation of the University of Tennessee Medical Center, Knoxville, which graciously provided a grant to fund this project. In addition, the National Park Service approved these sample collections (Approval GRSM-2012-SCI-1112) and provided invaluable advice to assist with sample collection and study design. This study was approved by the University of Tennessee Graduate School of Medicine's Institutional Review Board.

\section{References}

1. National Survey on Recreation and the Environment: 20002002. Available at: http://www.srs.fs.usda.gov/trends/Nsre/ Rnd1t11unweightrpt.pdf. Accessed January 7, 2015.

2. Boulware DR, Forgey WW, Martin WJ II. Medical risks of wilderness hiking. Am J Med. 2003;114:288-293.

3. Zarnoch SJ, Bowker JM, Cordell HK, Owens M, Green GT, Ginn A. Appalachian National Scenic Trail Pilot Survey. General Technical Report SRS-143 Asheville, NC: US Dept 
of Agriculture, Forest Service, Southern Research Station; 2011.

4. Gardner TB, Hill DR. Illness and injury among longdistance hikers on the Long Trail, Vermont. Wilderness Environ Med. 2002;13:131-134.

5. McIntosh SE, Leemon D, Visitacion J, Schimelpfenig T, Fosnocht D. Medical incidents and evacuations on wilderness expeditions. Wilderness Environ Med. 2007;18:298-304.

6. Crouse BJ, Josephs D. Health care needs of Appalachian Trail hikers. J Fam Pract. 1993:36:521-525.

7. Gove S, Slutkin G. Infections acquired in the fields and forests of the United States. Emerg Med Clin North Am. 1984;2:623-633.

8. Boulware DR. Influence of hygiene on gastrointestinal illness among wilderness backpackers. J Travel Med. 2004;11:27-33.
9. Silsbee DG, Larson GL. Bacterial water quality: springs and streams in the Great Smoky Mountains National Park. Environ Manage. 1982;6:353-359.

10. Centers for Disease Control and Prevention. Drinking Water Treatment Methods for Backcountry and Travel Use. 2009. Available at: http://www.cdc.gov/healthywater/ pdf/drinking/Backcountry_Water_Treatment.pdf. Accessed September 23, 2015.

11. Environmental Protection Agency, National primary drinking water regulations; total coliforms (including fecal coliforms and E. coli). Fed Regist. 1989;54: 27544-27568.

12. Larson GL, Mathews RC Jr, Klausmeyer JL. A survey of bacterial water quality in Abrams Creek, Great Smoky Mountains National Park. J Tenn Acad Sci. 1980;55:1-6. 